\title{
Effectiveness of albendazole against viability of entamoeba histolytica in mice and rabbits
}

\author{
Abdul-Salam M. Al-Mukhtar, Waleed J. Omar Barwari \\ Department of Microbiology, College of Medicine, University of Mosul.
}

(Ann. Coll. Med. Mosul 2008; 34(1): 64-68).

Received: $7^{\text {th }}$ Nov 2007; Accepted: $23^{\text {rd }}$ Apr 2008.

\begin{abstract}
ABSTRUCT
Objective: Intestinal amebiasis is still an important health problem in developing countries of the world. One of the issues for future biomedical research is the development of antimicrobial resistance, and the search for alternative new antiamoebic drugs. A study was carried out to evaluate the efficacy of albendazole on the viability of Entamoeba histolytica clinical isolate from human which was used for experimental animals.
\end{abstract}

Materials and Methods: All experimental animal models (18 albino mice and 18 rabbits), were divided into 6 groups, each group with either 6 mice or 6 rabbits, were orally infected with E. histolytica (clinical isolate), then after 7 days they were given drugs (Metronidazole or Albendazole) daily according to body weight prepared in advance for 5 days duration and in addition to the controls without drugs. Stool specimens of each group were examined microspically for viable trophozoites, and the number of these trophozoites were counted with haemocytometer chamber, as compared to untreated and treated groups. Statistical analysis was done by using Student's- t-test.

Results: The results showed infection of E. histolytica initiated in rabbits only. Albendazole and metronidazole were highly effective $(100 \%)$ for the treatment of infected groups of rabbits. Trphozoites of E. histolytica were highly sensitive to albendazole ( $25 \%$ viability), and metronidazole $(22.7 \%$ viability) at a dose of $400 \mathrm{mg} / \mathrm{kg} /$ day and $250 \mathrm{mg} / \mathrm{kg} /$ day, respectively, which was significant in relation to the control (500\% viability).

Conclusions: The present study showed that the newly used albendazole is very effective anti-amebic drug as metronidazole in rabbits.

الههف : داء المتحو لات المعوية الذي يسبيه الطفيلي لا تزال مشكلة صحية مهمة في المناطق النامية في العالم.

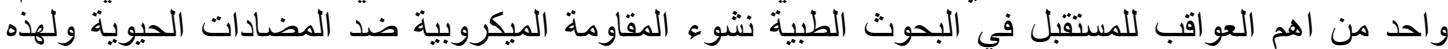

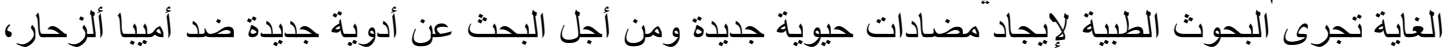
هدفت هذه الدر اسة حول تأثيثر تأثثير البندازول ضد حيوية الناثطات أميبا ألزحار و المعزولة سريريا من الأنسان على الحيو انات المختبرية.

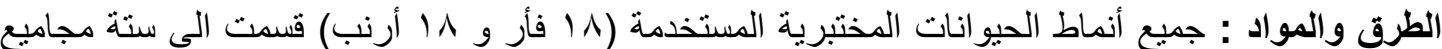

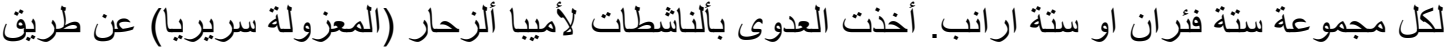

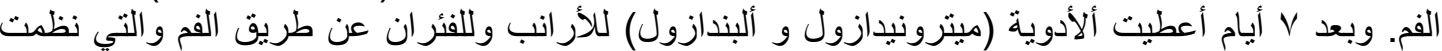

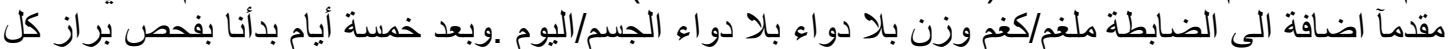

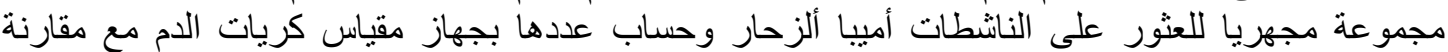

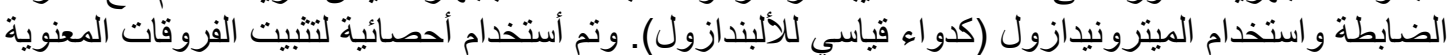

( Student t-test) 
النتائج : أظهرت النتائج ان جميع الفئر ان لم يحصل لهم أصابات ولكن على العكس كانت جميع الأر انب مصابة.

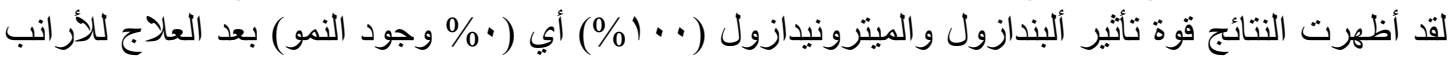

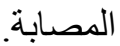

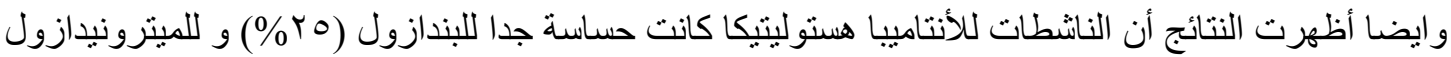
(\% ع Y.Y. ) حيث نسبة النمو .0\%\%. وكانت الفروقات معنوية عند مستوى (P<0.01).

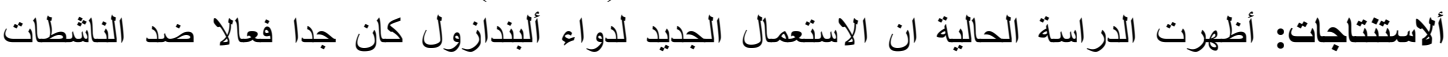

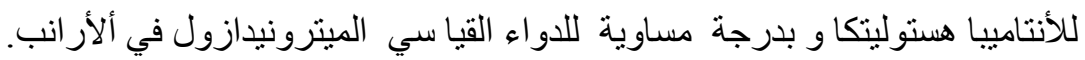

A moebiasis is world wide in distribution; it is much more common in the tropics and wherever sanitation is poor, in all climatic zones ${ }^{(1)}$. It constitutes one of the commonest protozoal infections on a global scale, and it is estimated to infect $10 \%$ of the world's population, up to 50 million cases of invasive amebiasis, and about 100,000 deaths and probably represent the third leading parasitic cause of death, behind only malaria and schistosomiasis ${ }^{(2,3)}$.

Amoebiasis is treated with metronidazole or one of 5-nitromidazol family of drugs such as tinidazole. Meronidazole is the only drug approved for the treatment of invasive amoebiasis, but it has side effects such as gastric upset, optic atrophy, bitter taste, dermatitis, seizures, and possible carcinogenesi $^{(4)}$. In addition, treatment failure which is about $20 \%$, raises concern about possible resistance to the used drugs and their use during pregnancy is risky ${ }^{(2)}$.

Although albendazole is an alternative drug for the treatment of giardiasis ${ }^{(5)}$, however, as far as we know albendazole experimentally was not tested against $\mathrm{E}$. histolytica infection. The aim of the present study is to evalute the effectiveness of (c) 2008 Mosul College of Medicine albendazole as an alternative drug against amoebiasis in experimental animals (mice and rabbits).

\section{MATERIALS and METHODS}

1. Mice: White albino mice (Balb/C strain) $8-10$ weeks old of both sexes obtained from animal house of Medical College, University of Mosul were used throughout the experimental work. The number of mice used in this study was 6 for each group, these mice were examined and found free from intestinal pathogens. Mice were kept in the animal house on normal performed food and in a suitable room temperature (20-25 $\left.{ }^{\circ} \mathrm{C}\right)$. The weight of mice ranged between 150-200 g.

2. Rabbits: Experiments were performed on local domestic rabbits (Oryctolagus cuniculus). The number of rabbits used in this study was 6 ( 3 males and 3 females) for each group, and were free from intestinal pathogens. Rabbits were kept in the animal house on normal available food (vegetables and bread) and in a suitable room temperature $\left(20-25^{\circ} \mathrm{C}\right)$. The weight of rabbits ranged between $1.3-1.6 \mathrm{~kg}$.The age of rabbits ranged between 9-12 months.

Stool samples : Samples were collected from patients naturally infected with $E$. histolytica from Azadi General Hospital in 
Duhok city /Iraq and a large number of cysts (infective stage) were isolated. Feces were diluted in water and sieved with gauze, then antibiotics (penicillin and streptomycin) were added, and cysts were isolated using sucrose gradients. Oral infections were done using about $10^{3}-10^{4}$ cysts/ml/ animal ${ }^{(5)}$.

All mice and rabbits were orally infected with $10^{3}-10^{4} / \mathrm{ml} \mathrm{E}$. histolytica cysts, and equally divided into groups, 6 animals for each group which were subjected for treatment with albendazole or metronidazole, and one untreated group was considered as a control one.

Each of the experimentally infected groups was treated with one type of the previously mentioned drugs and was administered orally with the help of a stomach tube through out, and were treated according to the recommended dose $(\mathrm{mg} / \mathrm{kg}$ body weight/day) for 5 days. Metronidazol $250 \mathrm{mg} / \mathrm{kg}$ three times daily ${ }^{(6)}$, albendazol $400 \mathrm{mg} / \mathrm{kg}$ once daily ${ }^{(5)}$.

The fecal samples were collected from each group and examined before and after treatment for the detection of the trophozoites or cysts. The effect of drugs was estimated by counting the mean Table (1): The percentage of cured rabbits in all groups after 5 days of treatment :

\begin{tabular}{|c|c|c|c||}
\hline Treated groups & No. of infected rabbits & $\begin{array}{c}\text { No. of cured rabbits after 5 } \\
\text { days of treatment }\end{array}$ & $\%$ of cured rabbits \\
\hline Saline control & 6 & 0 & $0 \%$ \\
\hline Metronidazol & 6 & 6 & $100 \%$ \\
\hline Albendazol & 6 & 6 & $100 \%$ \\
\hline
\end{tabular}

number of viable trophozoites using hemocytometer chamber ${ }^{(2)}$.

Statistical comparison was performed using Student's- t- test. Results were expressed as percentage of viability: = [number of viable trophozoites after treatment / number of viable trophozoites before treatment] $\times 100^{(7)}$.

\section{Results}

The results showed no infection was intiated with $E$. histolytica cyst in all mice used for in this experiment. On the contrary the result showed in all the rabbits used in this experiment infection was induced by E. histolytica cysts. The infection persisted among control group and the cure rate was $0 \%$. The drugs used were effective in the treatment groups with $100 \%$ cure rate (Table 1 ).

\section{Evaluation of the drug sensitivity for each group}

The percentages of trophozoites viability were nearly similar (22.7 and $25 \%$ ) among rabbits treated with albendazol and metronidazol respectively, which was significant at $p<0.05$ in comparision with the control group 500\%, (Table 2 ). 
Table (2): The effect of albendazole on the viability of E. histolytica in comparison with metronidazole and saline control in experimental rabbits:

\begin{tabular}{|c|c|c|c|}
\hline Treated groups & $\begin{array}{c}\text { No. of Trophozoites/ml } \\
\text { before treatment }\end{array}$ & $\begin{array}{c}\text { No. of Trophozoites } / \mathrm{ml} \\
\text { After five days of } \\
\text { treatment }\end{array}$ & \% of viability \\
\hline Saline control & 10000 & 50000 & 500 \\
\hline Metronidazole & 11000 & 2500 & 22.7 \\
\hline Albendazole & 10000 & 2500 & 25 \\
\hline
\end{tabular}

\section{Discussion}

All experimental mice used, showed no infection with E. histolytica. Several factors are involved in the successful infection with E. histolytica in rabbits. These include: strain of E. histolytica (clinical isolate) used, age ,weight, , diet, and the most important factors are the strain and the susceptibility of the host to E. histolytica ${ }^{(8)}$. Other workers reported that the experimental infection of rats with E. histolytica (clinical strain) are all virulent to rats, whereas those isolated from carriers were either unable to produce ulcers or had low virulence as compared to strains of $E$. histolytica isolated from acute cases $^{(9)}$. Our results indicate that the unsusceptiblety of mice and the type of strains of $E$. histolytica clinical isolate which were used, may explain the failure of mice to produce infection as is also indicated by other workers ${ }^{(9)}$. But in experimental rabbits the results showed that the percentage of trophozoites viability in control group was $500 \%$ after 5 days post-infection without treatment, which indicates progression of infection.

The percentage of trophozoites viability were only $22.7 \%$ or 25 after 5 days of treatment with metronidazol or albendazol respectively, which indicates excellent inhibition of growth as compared to the metronidazsol as a control. However, it must be stated that albendazole has not been tested in vivo (rabbits) against E. histolytica as far as literature cited.

As far as we know this is the first report of the albendazol sensitivity pattern to clinical isolates of $\mathrm{E}$. histolytica especially in context to widespread use of metronidazol which is available in many countries. Increased awareness and continued surveillance for the possible emergence of resistance among clinical isolates is necessary for the ultimate prevention and control of amoebiasis. Availability of a single agent efficacious against all forms of amoebae and with low levels of toxicity would be a major therapeutic advance, especially if the drug was safe to use during pregnancy.

\section{Conclusions}

In conclusion, albendazole was the best drug with excellent (100\%) effectiveness against E. histolytica in experimental rabbits as compared to metronidazole as a control. 


\section{References}

1. Paniker, CK.J.. Text book of Medical Parasitology, $5^{\text {th }}$ ed., New Delhi, India. Jaypee brothers Medical Publishers $(P)$ LTD. 2002;pp. 15-27.

2. Georgopoulos, A., Linnau K.F., Buxbaum A., Coste C., Santos M.A., Shabpar A., and Graninger W. Efficacy of macrolides vs. metronidazole against Entamoeba histolytica clinical isolates. The Middle European J of Medicine 2001; 113/1516: 593-596.

3. Bansal, D., Sehgal R., Chawla Y., Mahajan R.C., and Malla N. In vitro activity of antiamoebic drugs against clinical isolates of Entamoeba histolytica and Entamoeba dispar. Annals of Clinical Microbiol and Antimicrobials, 2004;3: 27-32.

4. Ravdin, J.I. Amebiasis: human infection by E. histolytica, printed in USA. A wiley Medical Publication. 1988;pp. 1-838.

5. Lemee, V., Zaharia I., Nevez G., Rabodonirina M., Ballet J.J., and Favennec L. Metronidazole and albendazole susceptibility of 11 clinical isolates of Giardia duodenalis from France. J Antimicrobial Chemotherapy, 2000;46: 819-821.
6. Chatterjee, D.K., Raether W., Lyer N., and Ganguli B.N. Caerulomycin, an antifungal antibiotic with marked in vitro and in vivo activity against Entamoeba histolytica. Z Parastenkd, 1984;70:569-573.

7. Al-Rawi, K.M.. Introduction to Statistics. The Ministry of Higher Education and Scientific Researches, published in Musol University, 1989;pp. 354-396.

8. Al-Jumaily, A.R.S. The effect of immunosupression of experimental amoebiasis in laboratory animals. M.Sc. thesis. College of Medicine, University of Baghdad.1983.

9. Das, S.R.; Sharma R.K.; and Ghoshal S. Virulence of strains of Entamoeba histolytica to rats and hamsters and their encystment In vitro. Indian J. Parasitol. 1978; 2: 15-18. 